\title{
The Effect of an Integrative Skills Program on Developing Jordanian University Students' Achievement in English
}

\author{
Oraib Hmoud Al-Faoury \\ Faculty of Languages and Translation, Imam Muhammad ibn Saud Islamic University, Riyadh, KSA \\ Nasser M. Freahat \\ Faculty of Languages and Translation, Imam Muhammad ibn Saud Islamic University, Riyadh, KSA
}

\begin{abstract}
This study aimed at investigating the effect of an integrative program, the effect of gender and the interaction between gender and the program on developing Jordanian university students' achievement in English .The participants of the study were 122 university students. The study adopted a quasi-experimental design. The data were collected using an achievement test which was validated and its interscorer reliability was ensured. ANCOVA was used to analyze the students' full degrees while MANCOVA was used to analyze their sub degrees of the test. The results revealed a significant difference between the adjusted mean scores of students' achievement in the posttest and a significant difference between the adjusted means for the students' achievement in the parts of the posttest. The results showed no significant difference between the adjusted mean scores of students due to gender and the interaction between gender and the teaching method. They also showed a significant difference between the means of the students' achievement in structures due to the interaction between the teaching method and gender in favor of the male while there was no statistically significant effect in vocabulary and reading comprehension.
\end{abstract}

Index Terms-integration, whole language approach, Jordan

\section{INTRODUCTION}

The idea of integrative skills has been widely emphasized and proved to be successful in developing the students' ability to use two or more of the four skills within real contexts and in a communicative framework (Finocchiaro and Bonomo, 1973; Hersan, 1998; Hobson and Schuman, 1990; Omaggio, 2001). Similarly, Omaggio (2001) highlights the importance of integrative skills for attaining higher levels of proficiency and addressing the goals of language study that have been articulated in the standards for foreign language learning.

Other researchers use the term Whole Language (WL) and clarify the significance of applying the whole language in their classes. Brown and Mothie (1984) explain how the students in their study became highly motivated. Weaver(1990) add that students developed positive attitude towards learning and viewed themselves as competent and responsible. Harp and Brewer (1991) emphasize the importance of WL in the language experience approach because it treats skills instruction in a meaningful context and aims at helping students be actively involved in learning that extends beyond the classroom to real communication. Lim and Watson (1993) emphasize the role of integrative programs in developing the students' cognitive and academic achievement and their abilities to be risk takers in expressing themselves regardless of the linguistic demands and the possibility of making errors.

It is evident that the four language skills are rarely used in segregation in everyday life. The researchers, therefore, aim to integrate them in a proposed instructional program in order to develop the students' abilities to interact socially, communicate efficiently, and produce successfully correct language structures in various situations.

Problem of the Study

Brown (1994) suggests that learning a second language may be difficult, especially for adults who already have a strong foundation in their own native language. English is a key language taught in the Jordanian EFL context. Yet, the researchers noticed that Jordanian university students' suffer from weakness in their communicative competence during their experience in the Jordanian educational context; the students lacked the ability to communicate easily in English. This may be due to the minimal exposure to English in general and to integrative activities in particular. In light of the findings of the reviewed literature, the researchers aim to implement a program of integrative skills to investigate its effect on developing the students' achievement. To the researchers' best knowledge, the effect of an integrative skills program on developing Jordanian University students' achievement has never been researched.

Purpose

The purpose of this study is to investigate the effect of an integrative skills program on developing Jordanian University students' achievement.

Questions 
The authors seek answers to the following questions:

1. Are there statistically significant differences in students' achievement in English (vocabulary, grammar and reading comprehension) ( $\alpha=0.05$ ) due to the instructional program?

2. Are there statistically significant differences in students' achievement in English (vocabulary, grammar and reading comprehension) $(\alpha=0.05)$ due to gender?

3. Are there statistically significant differences in students' achievement in English (vocabulary, grammar and reading comprehension) $(\alpha=0.05)$ due to the interaction between gender and the instructional program)?

\section{Significance of the study}

The findings are potentially significant for the students since they are expected to develop their achievement in English. The other instructors might also benefit from the findings of this study by reflecting on their methods of teaching by helping their students use the target language.

\section{Previous Literature}

Jacobs (1991) believes that the basis of integration is based on the student- centered process and making students shoulder their own responsibilities for teaching themselves. Freeman and Freeman (1992) emphasize the importance of integrative skills and criticize the traditional L2 approaches by indicating that they have a tendency to make language learning difficult for L2 learners because it is hard to understand individual parts isolated from the whole context. Other researchers use the term Integrative Approach (IA) to refer to the integration of language which encourages the teacher and the learner to look at language not in segments but as a whole.

Rigg (1991) states that the WLA views language as "a means for the creation and communication of meaning" (p. 523-4). He emphasizes that WLA emphasizes the importance of written and oral languages which are considered simultaneously acquired. He adds that WLA stresses the importance of taking into consideration the speaker, the recipient, the tool of communication, the reason for communicating, the purposes of the speakers, the social relationship between them, the situation and pragmatic, semiotic and cultural aspects of language. Likewise, Lake (2001) emphasizes the importance of integrated curriculum since it helps students apply skills, foster retrieval of information, leads to a more integrated knowledge base, encourages depth and breadth in learning, promotes positive attitudes in students and provides more time for curriculum exploration.

In their study about the differences between traditional teaching and WL teaching, Wixon, Peter and Potter (1996) state that WL is learner- centered and literature based, they add that skills are taught in a rich context in WL. They stress that teachers are empowered to emphasize writing, verbal interaction, parent involvement, self-esteem, flexible grouping and a variety of strategies in WL. Furthermore, Larsen-Freeman (2000) confirms that "Whole Language educators see errors as part of learning and they encourage students to experiment with reading and writing to promote both their enjoyment and ownership" (p.143).

Supporters of WLA urge teachers to create friendly classroom conditions in order to help learners experiment with the language. With regards to the same issue, Graham and Harris (1994) urge WL teachers to strive to create supportive, pleasant and nonthreatening classroom conditions. Furthermore, Smith (1983) clarifies the importance of this setting in helping students build on their own prior knowledge and operate on their own developing "hypotheses" about how oral and written language operate. Similarly, Newman (1985) signifies the importance of this atmosphere in helping learners discover rules through meaningful usage and real life experiences, explore though variety of self-selected material and apply divergent thinking, experimenting and rereading for more information. Goodman, Goodman and Hood (1986) add that the friendly atmosphere helps students "see relationships among ideas and concepts as they plan and experience a theme-based inquiry" (P. 31). Furthermore, Lipson (1993) emphasizes that informal natural conditions in WLA help students realize that language and meaning are inseparable, he adds that such conditions help students collaborate, invent, discover and learn authentic texts in contextualized language.

In a study about the effectiveness of WLA on improving the language skills of selected community college students, Crawford (1993) reports that students in the WL group scored significantly higher on reading and writing tests. In another study about the effect of whole language instruction on developing black students' reading and writing at a historically black college, Long (1996) reports that the experimental group scored higher on grammar and reading final exams as compared to the control group, the experimental group also passed English 112 and History 130 at a higher rate than the control group. Class attendance and attitude of the experimental group was better as compared to that of the control group.

In his study of the effectiveness of using the WLA with the help of the computer in improving the learners' writing ability in a foreign language at Holy Family University, Dawid (2004) reports that WLA improves students' ability to express themselves and take greater risks in using the language. In his study of the effectiveness of a proposed EFL integrative program based on the WLA on the basic stage students' achievement in English, Shatnawi (2005) reports differences in favor of the experimental group. The findings also indicated significant differences in favor of female students and a ranking interaction between the method of teaching and the gender. In another study about the effects an integrative approach on improving word recognition and reading comprehension among intermediate L2 readers, Askildson (2008) supports the significant efficacy of the integrative approach in reading rate, comprehension, vocabulary and grammatical knowledge. 


\section{Method AND PROCEDURES}

This research is essentially quantitative. The sample of the study consisted of 122 students studying English Communication Skills (102) at Philadelphia University in the first semester of the academic year 2011/2012 and those students were chosen purposefully. The researchers chose the students in the courses which one of them taught in order to apply the program of the integrative skills, the first group $(\mathrm{N}=62)$ was the control group (male and female students). The second group $(\mathrm{N}=60)$ was the experimental group (male and female students). The experimental group was instructed using the integrative skills program. The control group, on the other hand, was taught using the material in Intermediate New Headway Plus following the teacher's guidelines to teach the skills. The participants were informed about the experiment in the sense that it was a study about an integrative skills program.

The distribution of the sample according to the variables of gender and teaching method is presented in Table 1.

TABLE 1:

THE Distribution OF THE PARTICIPANTS Due to INDEPENDENT VARIABLES (GENDER AND TEACHING METHOD)

\begin{tabular}{|c|c|c|c|c|c|c|}
\hline \multirow{3}{*}{ Teaching Method } & \multicolumn{4}{|c|}{ Gender } & \multirow{2}{*}{\multicolumn{2}{|c|}{ Total }} \\
\hline & \multicolumn{2}{|c|}{ Male } & \multicolumn{2}{|c|}{ Female } & & \\
\hline & \# & $\%$ & \# & $\%$ & \# & $\%$ \\
\hline Traditional & 34 & 27.9 & 28 & 23.0 & 62 & 50.8 \\
\hline Integrative & 35 & 28.7 & 25 & 20.5 & 60 & 49.2 \\
\hline Total & 69 & 56.6 & 53 & 43.5 & 122 & 100.0 \\
\hline
\end{tabular}

A content analysis research tool was conducted to find out the percentages of integrative skills in the first six chapters in Intermediate New Headway Plus. The criteria of analysis in this research included the extent of incorporating the four skills in the units and activities under study. The unit of analysis in this study was the activity and the categories of analysis were the integrative skills in the Students' book.

An analysis of the activities under study was conducted by one of the researchers in light of the categories of the analysis in order to establish the reliability of the content analysis of integrative skills. Regarding the intra-rater reliability, a repetition of the analysis three weeks later was attempted using the same unit and categories of analysis and the percentage coefficient of the whole analysis of the integrative skills was $98 \%$, which is considered very high. The other researcher with another analyst familiar with content analysis conducted the content analysis on all of the activities under study using the same categories and unit of analysis. The inter-rater reliability coefficient (agreement percentage) for the integrative skills was calculated and the three coefficients were $(98.8 \%, 97 \%$ and $98 \%)$ which are considered very high.

The researchers constructed an achievement test and administered it to the students in order to examine the equivalence between the experimental and the control groups. Then, they administered it as a posttest to examine the effect of implementing the program on the students' achievement. The focus of the questions was vocabulary items, structures and reading comprehension. A jury of experts judged the content validity of the achievement test which consisted of ten reading comprehension items, twenty vocabulary items and twenty structural items. The jury had a few suggestions and recommendations which were taken by the researchers and modified accordingly.

Difficulty and discrimination coefficients were calculated for each individual part of the test: reading comprehension, vocabulary and structures. The items of the reading comprehension were related to each other with correlations ranging between .50 and .71 and they were related with the whole achievement test with correlations ranging between .45 and .65. The items of vocabulary were related to each other with correlations ranging between .42 and .82 and they were related with the whole achievement test with correlations ranging between .40 and .82 . The items of structure were related to each other with correlations ranging between .46 and .83 and they were related with the whole achievement test with correlations ranging between .40 and .96 .

To establish the internal consistency, the test was applied on a pilot group of 30 male and female students studying English Communication skills (102) who were excluded from the study sample using test/ retest method. The value of stability index for the achievement test was computed using KR 20 and the value of the retest reliability was computed using Pearson Correlation, as shown in Table 2 below. 
TABLE 2:

STABILITY INDEX AND INTERNAL CONSISTENCY COEFFICIENTS FOR THE ACHIEVEMENT TEST

\begin{tabular}{llll}
\hline Pearson Correlation & Reading Comprehension & Vocabulary & Structure \\
\hline Vocabulary & 0.37 & & \\
Structure & 0.35 & 0.36 & \\
\hline Achievement & 0.56 & 0.81 & 0.77 \\
\hline Achievement and its Dimensions & KR 20 & Stability Index & N of Items \\
\hline Reading Comprehension & 0.78 & 0.90 & 10 \\
\hline Vocabulary & 0.90 & 0.85 & 20 \\
\hline Structure & 0.85 & 0.87 & 20 \\
\hline Over Whole & 0.93 & 0.86 & 50 \\
\hline
\end{tabular}

Table 2 shows that the value of stability index ranged between .78 and .85 . The value of the retest reliability was .86 and it ranged between .85 and .90 . The table shows that the domains of the achievement test are related with the achievement test with values ranging between .56 and. 81. The values of interconnections range between for the domains range between .35 and .37 .

The researchers developed a grading system for assessing the students' achievement test as a whole. The test was divided into three parts, each focusing on a particular linguistic aspect. These parts included: reading comprehension, vocabulary and structures. As for the reading comprehension part, it included 10 major questions worth 10 points. For the vocabulary part, 20 questions were asked with 1 point allocated to each. Finally, the students had to choose the most appropriate grammatical choice in the structures part; henceforth, 20 points were allocated for this part of the test. The reason behind the researchers' choice of questions was basically to measure the different linguistic elements before and after the instructional program.

Having analyzed the integration of the skills in Intermediate New Headway Plus, the researchers developed a program which aims at providing students with integrated skills in order to make them use the four skills of the language simultaneously and purposefully. The instructional material used in the present study was based on the activities in Intermediate New Headway Plus along with the researchers' designed material used to complement any shortage in the textbook in order to cover all of the four skills of the language. Once the material was compiled and modified at some point to suit the objectives of the instructional program, it was incorporated among the other skills and activities.

The instructional program was carried out by one of the researchers during the first semester of the academic year 2011/ 2012 for the experimental group and lasted for four months. Likewise, the control group was taught by the same researcher using the material in Intermediate New Headway Plus during the same semester.

To answer the questions of the study, an analysis of covariance (ANCOVA) was used to analyze the students' whole achievement in English while a multiple analysis of covariance (MANCOVA) was used to analyze the students' sub degrees on the dimensions of the achievement test.

To conduct the study, a systematic content analysis for the integrative skills in New Intermediate Headway Plus textbook was carried out by the use of frequencies and percentages and repeated three weeks later by one of the researchers. The other researcher along with another analyst conducted separate content analyses on all of the activities of the Students' Textbooks using the same unit and categories of analysis. Validity and reliability of the instruments were established. The achievement test was rewritten by the researchers and distributed to the sample of the study. The instructional program was constructed in which the activities were redesigned in light of the findings of the content analysis and according to the integrative method. The integrative skills program was applied by one of the researchers in the experimental group for four months while the controlled group was taught the textbook conventionally by the same researcher. The achievement test was reapplied as post tests in order to investigate the effect of the integrative skills program on developing the students' achievement in English

\section{FINDINGS AND DisCUSSION}

To answer the research questions, which seek to identify whether or not there are any statistical differences in Jordanian students' achievement in English due to the teaching method, the gender of the students or the interaction between the teaching method and the gender of the students, means and standard deviations of the pre and posttest scores were investigated, as shown in Table 3. 
TABLE 3:

Means and Standard Deviations of THe Pre AND PostTest SCORES Due to the Teaching Method, GENDER OR THE INTERACTION BETWEEN THEM

\begin{tabular}{|c|c|c|c|c|c|c|c|}
\hline \multirow{2}{*}{$\begin{array}{l}\text { Teaching } \\
\text { Method }\end{array}$} & \multirow[t]{2}{*}{ Gender } & \multicolumn{2}{|c|}{$\begin{array}{l}\text { Achievement } \\
\text { (Covariate) }\end{array}$} & \multicolumn{4}{|c|}{ Achievement } \\
\hline & & Mean & Std. Dev. & Mean & Std. Dev. & Adj. Mean & Std. Error \\
\hline \multirow[t]{3}{*}{ Conventional } & Male & 31.294 & 4.83 & 36.735 & 4.09 & 37.153 & 0.73 \\
\hline & Female & 31.786 & 4.83 & 38.964 & 6.96 & 39.178 & 0.81 \\
\hline & Total & 31.516 & 4.80 & 37.742 & 5.64 & 38.166 & 0.55 \\
\hline \multirow[t]{3}{*}{ Integrative } & Male & 31.400 & 6.92 & 46.577 & 4.31 & 46.951 & 0.72 \\
\hline & Female & 35.520 & 5.91 & 47.628 & 3.48 & 46.297 & 0.88 \\
\hline & Total & 33.117 & 6.79 & 47.015 & 3.99 & 46.624 & 0.56 \\
\hline \multirow[t]{2}{*}{ Total } & Male & 31.348 & 5.94 & 41.728 & 6.48 & 42.052 & 0.52 \\
\hline & Female & 33.547 & 5.64 & 43.051 & 7.06 & 42.738 & 0.59 \\
\hline
\end{tabular}

Table 3 indicates an observed difference between the means of the students' achievement in the posttest due to the teaching method and gender. To examine whether or not these differences between the mean scores of the aforementioned groups were significant, two-way interaction ANCOVA was used for the scores of the students' achievement in the posttest, based on IVs, as shown in Table 4.

TABLE 4:

ANCOVA For the Students’ MeAn SCORES OF THE ACHIEVEMENT PostTEST Due to the TEACHING METHOD, GENDER OR THE INTERACTION BETWEEN THEM

\begin{tabular}{|c|c|c|c|c|c|c|}
\hline Source & Sum of Squares & $\mathrm{df}$ & Mean Square & $\mathrm{F}$ & Sig. & Partial $\eta 2$ \\
\hline Achievement (Covariate) & 662.411 & 1 & 662.411 & 36.521 & 0.000 & $23.79 \%$ \\
\hline Teaching Method & 2081.201 & 1 & 2081.201 & 114.743 & 0.000 & $49.51 \%$ \\
\hline Gender & 13.524 & 1 & 13.524 & 0.746 & 0.390 & $0.63 \%$ \\
\hline Teaching Method * Gender & 52.357 & 1 & 52.357 & 2.887 & 0.092 & $2.41 \%$ \\
\hline Error & 2122.143 & 117 & 18.138 & & & \\
\hline Total & 5498.929 & 121 & & & & \\
\hline
\end{tabular}

Table 4 shows that there was a statistically significant difference at $\alpha=0.05$ between the adjusted mean scores of students' achievement in the posttest due to the teaching method in favor of the students in the experimental group who were taught using the integrative method. This table shows that the size of effect for the teaching method was $49.51 \%$ which means that the teaching method is correlated with the students' achievement in the posttest in a rational correlation according to Abu-Hatab and Cohen citation. (Al-Sharbeenee, 1995, P. 80-81).

The same table also shows that there was no statistically significant difference at $(\alpha=0.05)$ between the adjusted mean scores of students' achievement in the posttest due to gender or the interaction between gender and the teaching method. In addition, the means and standard deviations for students' achievement in Reading Comprehension, Vocabulary and structures in the pre and posttests were calculated based on IVs along with the adjusted means and the standard errors for students' achievement in the parts of the pretest, as presented in Table 5 below. 
TABLE 5:

MEANS AND STANDARD DEVIATIONS FOR THE SCORES ON THE PARTS OF THE PRE AND POSTTESTS AS A RESUlT OF THE TEACHING METHOD AND GENDER

\begin{tabular}{|c|c|c|c|c|c|c|c|c|}
\hline \multirow{2}{*}{ Dimension } & \multirow{2}{*}{$\begin{array}{l}\text { Teaching } \\
\text { Method }\end{array}$} & \multirow{2}{*}{ Gender } & \multicolumn{2}{|l|}{ Pretest } & \multicolumn{4}{|l|}{ Posttest } \\
\hline & & & Mean & Std. Dev. & Mean & Std. Dev. & Adj. Mean & Std. Error \\
\hline \multirow{8}{*}{ Reading Comprehension } & \multirow[t]{3}{*}{ Conventional } & Male & 5.853 & 1.48 & 6.735 & 1.73 & 6.875 & 0.23 \\
\hline & & Female & 6.357 & 1.47 & 7.429 & 1.73 & 7.356 & 0.26 \\
\hline & & Total & 6.081 & 1.49 & 7.048 & 1.75 & 7.116 & 0.17 \\
\hline & \multirow[t]{3}{*}{ Integrative } & Male & 5.714 & 1.66 & 9.217 & 1.27 & 9.392 & 0.23 \\
\hline & & Female & 6.880 & 1.17 & 9.336 & 0.84 & 8.982 & 0.28 \\
\hline & & Total & 6.200 & 1.57 & 9.267 & 1.11 & 9.187 & 0.18 \\
\hline & \multirow[t]{2}{*}{ Total } & Male & 5.783 & 1.56 & 7.994 & 1.96 & 8.134 & 0.16 \\
\hline & & Female & 6.604 & 1.35 & 8.328 & 1.67 & 8.169 & 0.19 \\
\hline \multirow[t]{8}{*}{ Vocabulary } & \multirow[t]{3}{*}{ Conventional } & Male & 11.765 & 3.61 & 15.559 & 2.90 & 15.801 & 0.49 \\
\hline & & Female & 12.536 & 2.73 & 15.821 & 4.17 & 15.878 & 0.54 \\
\hline & & Total & 12.113 & 3.24 & 15.677 & 3.51 & 15.840 & 0.36 \\
\hline & \multirow[t]{3}{*}{ Integrative } & Male & 12.343 & 3.95 & 18.314 & 3.05 & 18.343 & 0.48 \\
\hline & & Female & 13.840 & 3.87 & 19.180 & 1.22 & 18.746 & 0.58 \\
\hline & & Total & 12.967 & 3.95 & 18.675 & 2.48 & 18.545 & 0.37 \\
\hline & \multirow[t]{2}{*}{ Total } & Male & 12.058 & 3.77 & 16.957 & 3.27 & 17.072 & 0.34 \\
\hline & & Female & 13.151 & 3.35 & 17.406 & 3.55 & 17.312 & 0.40 \\
\hline \multirow[t]{8}{*}{ Structure } & \multirow[t]{3}{*}{ Conventional } & Male & 13.676 & 2.80 & 14.441 & 2.48 & 14.500 & 0.33 \\
\hline & & Female & 12.893 & 2.17 & 15.714 & 2.76 & 15.897 & 0.37 \\
\hline & & Total & 13.323 & 2.55 & 15.016 & 2.66 & 15.199 & 0.24 \\
\hline & \multirow[t]{3}{*}{ Integrative } & Male & 13.343 & 3.77 & 19.046 & 1.83 & 19.257 & 0.33 \\
\hline & & Female & 14.800 & 3.03 & 19.112 & 1.84 & 18.531 & 0.40 \\
\hline & & Total & 13.950 & 3.53 & 19.073 & 1.82 & 18.894 & 0.25 \\
\hline & \multirow[t]{2}{*}{ Total } & Male & 13.507 & 3.31 & 16.777 & 3.17 & 16.879 & 0.23 \\
\hline & & Female & 13.792 & 2.76 & 17.317 & 2.91 & 17.214 & 0.27 \\
\hline
\end{tabular}

Table 5 shows the presence of a statistical difference in the means of the students' scores on the parts of the posttest due to the teaching method and gender. To determine the most appropriate analysis of covariance to use in order to detect any statistical differences in the scores of the parts in the achievement test, the correlation that exists among the scores of the part of the posttest was first calculated, after which the Barlett's Test of Sphersity was used to find if there were statistical significant correlation based on IVs, as shown in Table 6 below.

TABLE 6:

CORRELATION AMONG THE SCORES OF THE PARTS ON THE POSTTEST AND THE RESUlTs ACCORDING TO THE BARLETT'S TEST

\begin{tabular}{lll}
\hline Correlation & Reading Comprehension & Vocabulary \\
\hline Vocabulary & 0.10 & \\
Structure & 0.10 & 0.37 \\
\hline Bartlett's Test of Sphericity & \\
\hline Likelihood Ratio & 0.000 \\
$\chi 2$ & 77.903 \\
df & 5 \\
Sig. & 0.000 \\
\hline
\end{tabular}

It is evident from Table 6 that there exists statistical correlation at $\alpha=0.05$ among the scores of the sub-parts of the posttest due to both of the IVs, and as such, MANCOVA is used; the results are presented in Table 7 below.

TABLE 7:

MANCOVA RESUlts FOR THE SCORES IN THE SUB-PARTS OF THE POSTTEST As A RESUlt OF THE TEACHING METHOD AND GENDER

\begin{tabular}{|c|c|c|c|c|c|c|c|}
\hline Effect & MANOVA test & Value & $\mathrm{F}$ & Hypothesis df & Error df & Sig. & Partial $\eta 2$ \\
\hline Reading Comprehension (Covariate) & Wilks' Lambda & 0.84 & 7.07 & 3 & 113 & 0.000 & $15.80 \%$ \\
\hline Vocabulary (Covariate) & Wilks' Lambda & 0.79 & 10.03 & 3 & 113 & 0.000 & $21.02 \%$ \\
\hline Structure (Covariate) & Wilks' Lambda & 0.81 & 8.73 & 3 & 113 & 0.000 & $18.81 \%$ \\
\hline Teaching Method & Hotelling's Trace & 1.42 & 53.47 & 3 & 113 & 0.000 & $58.67 \%$ \\
\hline Gender & Hotelling's Trace & 0.01 & 0.28 & 3 & 113 & 0.842 & $0.73 \%$ \\
\hline Teaching Method $*$ Gender & Wilks' Lambda & 0.89 & 4.53 & 3 & 113 & 0.005 & $10.73 \%$ \\
\hline
\end{tabular}

Table 7 shows that there was a statistically significant effect at $\alpha=0.05$ of the two variables (the teaching method and gender) on the mean scores of students' achievement in the parts of the posttest altogether. To find out on which part those significant differences were found due to the method of teaching and the interaction, ANCOVA was used for every part of the post achievement test separately based on IVs, :as shown in Table 8 below. 
TABLE 8:

RESUlTS OF TWO - WAY ANALYSIS OF COVARIANCE BETWEEN MEAN SCORES OF THE PARTS OF ACHIEVEMENT TEST CONCERNING GENDER AND THE TEACHING METHOD

\begin{tabular}{|c|c|c|c|c|c|c|c|}
\hline $\begin{array}{l}\text { Dependent } \\
\text { Variable }\end{array}$ & Source & $\begin{array}{l}\text { Sum of } \\
\text { Squares }\end{array}$ & df & $\begin{array}{l}\text { Mean } \\
\text { Square }\end{array}$ & $\mathrm{F}$ & Sig. & $\begin{array}{l}\text { Partial } \\
\eta 2\end{array}$ \\
\hline Reading & Reading Comprehension (Covariate) & 28.697 & 1 & 28.697 & 16.031 & 0.000 & $12.23 \%$ \\
\hline \multirow[t]{7}{*}{ Comprehension } & Vocabulary (Covariate) & 2.383 & 1 & 2.383 & 1.331 & 0.251 & $1.14 \%$ \\
\hline & Structure (Covariate) & 0.177 & 1 & 0.177 & 0.099 & 0.754 & $0.09 \%$ \\
\hline & Teaching Method & 124.631 & 1 & 124.631 & 69.621 & 0.000 & $37.71 \%$ \\
\hline & Gender & 0.032 & 1 & 0.032 & 0.018 & 0.893 & $0.02 \%$ \\
\hline & Teaching Method $*$ Gender & 5.731 & 1 & 5.731 & 3.201 & 0.076 & $2.71 \%$ \\
\hline & Error & 205.865 & 115 & 1.790 & & & \\
\hline & Total & 409.031 & 121 & & & & \\
\hline \multirow{8}{*}{ Vocabulary } & Reading Comprehension (Covariate) & 2.899 & 1 & 2.899 & 0.372 & 0.543 & $0.32 \%$ \\
\hline & Vocabulary (Covariate) & 197.004 & 1 & 197.004 & 25.290 & 0.000 & $18.03 \%$ \\
\hline & Structure (Covariate) & 1.417 & 1 & 1.417 & 0.182 & 0.671 & $0.16 \%$ \\
\hline & Teaching Method & 212.552 & 1 & 212.552 & 27.286 & 0.000 & $19.18 \%$ \\
\hline & Gender & 1.544 & 1 & 1.544 & 0.198 & 0.657 & $0.17 \%$ \\
\hline & Teaching Method $*$ Gender & 0.769 & 1 & 0.769 & 0.099 & 0.754 & $0.09 \%$ \\
\hline & Error & 895.819 & 115 & 7.790 & & & \\
\hline & Total & 1386.445 & 121 & & & & \\
\hline \multirow[t]{8}{*}{ Structure } & Reading Comprehension (Covariate) & 14.927 & 1 & 14.927 & 4.107 & 0.045 & $3.45 \%$ \\
\hline & Vocabulary (Covariate) & 0.072 & 1 & 0.072 & 0.020 & 0.888 & $0.02 \%$ \\
\hline & Structure (Covariate) & 88.541 & 1 & 88.541 & 24.364 & 0.000 & $17.48 \%$ \\
\hline & Teaching Method & 396.571 & 1 & 396.571 & 109.126 & 0.000 & $48.69 \%$ \\
\hline & Gender & 3.023 & 1 & 3.023 & 0.832 & 0.364 & $0.72 \%$ \\
\hline & Teaching Method $*$ Gender & 32.564 & 1 & 32.564 & 8.961 & 0.003 & $7.23 \%$ \\
\hline & Error & 417.919 & 115 & 3.634 & & & \\
\hline & Total & 1129.384 & 121 & & & & \\
\hline
\end{tabular}

Table 8 shows that there was a statistically significant effect at $\alpha=0.05$ between the adjusted means for the students' achievement in the parts of the posttest due to the proposed teaching method in favor of the students who were taught in the integrative method compared with the students who were taught using the conventional method. The size of effect was $37.71 \%$, for reading comprehension, $19.18 \%$ for vocabulary and $48.69 \%$ for structures which shows a high correlation between the teaching method and the parts of the achievement test. Table 8 also shows that there was a statistically significant effect at $\alpha=0.05$ between the means of the students' achievement in structures in the posttest due to the interaction between the teaching method and gender. In order to illustrate the effect of the interaction between gender and the teaching method, Figure 1was presented.

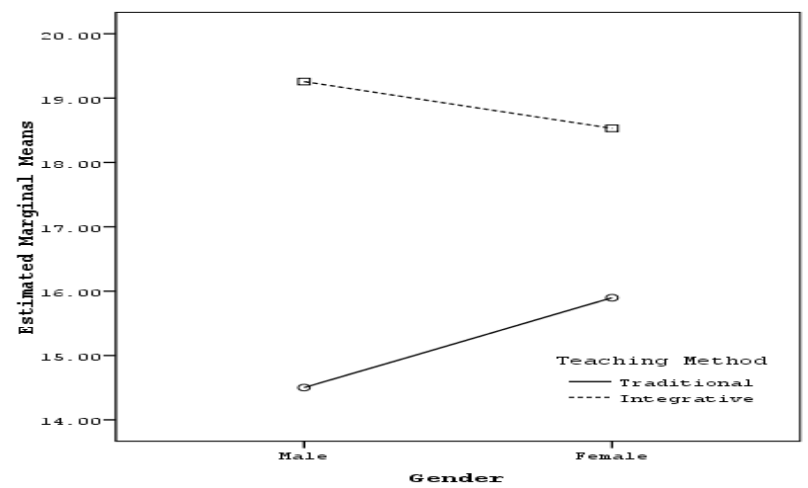

Figure 1: Line Graph of the Interaction between Gender and the Teaching Method and its Effect on the Posttest

Figure 1 shows that male students have made more progress than female students in the experimental group while female students have made more progress than male students in the control group.

\section{CONCLUSIONS}

It was clear from the findings of the study that there was a statistically significant difference at $\alpha=0.05$ between the adjusted mean scores of students' achievement in the posttest due to the teaching method in favor of the students in the experimental group who were taught using the integrative method. The size of effect for the teaching method was $49.51 \%$ which means that the teaching method is related to the students' achievement in the posttest in a rational correlation. The results of the study also showed that there was a statistically significant effect at $\alpha=0.05$ between the adjusted means for the students achievement in the parts of the posttest (reading comprehension, vocabulary and structures) due to the proposed teaching method in favor of the students in the experimental group. The size of effect 
was $37.71 \%$, for Reading comprehension, $19.18 \%$ for vocabulary and $48.69 \%$ for structures which shows a rational correlation between the teaching method and the parts of the achievement test. As can be concluded from these numbers, there was a significant difference between the mean scores in favor of the experimental group due to the effect of teaching students according to the proposed teaching program.

It is clear by the scores of the experimental group that the instructional program did have a positive impact on the students' achievement. Utilizing the Whole Language Approach and the integrative method might contribute a lot to improving the quality of students' language abilities and providing them with more and better opportunities to practice language skills during English lessons in the classroom. The classes in the experimental group were students- centered and students were more motivated in practicing the four language skills simultaneously. Thus, the development of the linguistic abilities is logically justified and expected. This result is supported by the findings of other researchers (e.g. Askildson, 2008; Crawford, 1993; Dawid, 2004; Long, 1996) whose results provided evidence in favor of the students who were taught according to the integrative program.

Concerning reading comprehension, the findings of the study revealed that there was progress in the experimental group students' performance in the reading skill which could be attributed to the big amount of reading students in the experimental group practiced during the experiment. Moreover, reading is the base of the teaching and learning process in the proposed program. The afore-mentioned finding is in line with the findings of other researchers (e.g. Askildson, 2008; Long, 1996;) who indicated that using the Whole Language approach and the integrative method does improve students' reading in quality and quantity. Concerning vocabulary, the findings of the study revealed that there was progress in the experimental group students' performance in vocabulary which could be attributed to the integrative teaching in which language and meaning are inseparable. The afore-mentioned finding is in line with the findings of other researchers (e.g Askildson, 2008) who indicate that WLA develops students' achievement in vocabulary. Concerning structures, the findings of the study revealed that there was progress in the experimental group students' performance in grammar which could be attributed to the whole language teaching in which grammar is contextualized and developed with all skills. The afore-mentioned finding is in line with the findings of other researchers (e.g. Askildson, 2008; Long, 1996) who indicate that WLA develops students' achievement in grammar.

Furthermore, this result agrees with the theoretical assumptions cited in the background of the study. Many researchers (e.g Dawid, 2004; Lim and Watson, 1993) emphasize the effectiveness of the Whole Language approach and the integrative method in developing students' language abilities in general. They point out that the integration between language arts helps students attain higher levels of proficiency and develop the students' cognitive achievement and their abilities to be risk takers in expressing themselves regardless of the linguistic demands and the possibility of making errors.

It was clear from the findings of the study that there was no statistically significant difference at $\alpha=0.05$ between the adjusted mean scores of students' overall achievement in the posttest due to gender and the interaction between gender and teaching method, whereas there was a statistically significant effect at $\alpha=0.05$ between the means of the students' achievement in the parts of the post test. The results showed that there was a statistically significant effect at $\alpha=0.05$ between the means of the students' achievement in structures in the posttest due to the interaction between teaching method and gender. This result is different from the findings of some other studies such as Shatnawi (2005) whose results indicated significant differences in favor of female students and a ranking interaction between the method of teaching and the gender.

There was no statistically significant effect at $\alpha=0.05$ between the means of the students' achievement in reading comprehension and vocabulary in the posttest that can be attributed to gender. The researcher thinks that there were no statistical differences because male and female students who participated in the experiment were similar in their age and they had the same educational, social and economic background and all of them were taught in the integrative method without any discrimination between males and females which might have developed the males' linguistic abilities in the reading comprehension and vocabulary to the extent that they performed as proficient as females in the two previously mentioned parts.

Nevertheless, male students were superior and better than their female counterparts in structures only. This result is different from the findings of some other studies such as Shatnawi (2005) whose results indicated a significant difference in favor of the females in the experimental group. The disagreement between the last study and the current study could be attributed to the fact that there were certain grammatical questions that stimulated the logical intelligence, which males are usually superior in according to Gardner (1983), which helped students understand syntax, analyze the semantics of the language and solve the problems correctly and thus males performed better than females. For example, the third and fourth questions in structures lacked the clear clues of the tense and thus students who answered those questions correctly had to analyze the context and find out that it expressed past actions that have present results in order to choose the present perfect tense rather than the past simple one. In the fifth question, students had to analyze the context that lacked a clear cue word in order to differentiate between the use of temporary, permanent and finished actions in order to choose the right tense. In the ninth question, students had to differentiate between actions in active and passive voices taking into consideration the right tense and use in the context in order to answer the question correctly. Thus, the researcher thinks that the superiority and higher level of language abilities of male students in structures during the experiment is a natural and logical outcome. 
In conclusion, within the limitations of this study, it appears that Integrating listening, speaking, reading and writing develops students' whole achievement in English as well as students' achievement in vocabulary, grammar and reading comprehension.

\section{Recommendations}

Based on the findings of this study, researchers are recommended to analyze the extent of integration in syllabuses of English communication skills taught in different language centers.

\section{Pedagogical Implications}

Jordanian universities are recommended to design training courses and workshops for EFL teachers on the strategies of teaching integrative English skills. Local Textbook writers are recommended to design more integrative activities that provide students with opportunities to use the four skills meaningfully in every exercise. EFL teachers are recommended to recognize the importance of WLA which calls for student-centered learning environment, to provide students with more activities that stimulate students' ability to use the four skills integratively, to vary their methods of teaching to individualize learning and help students develop their linguistic abilities and to incorporate integrated activities in assessment practices in order to develop the students' academic linguistic achievement in English.

\section{REFERENCES}

[1] Al- Sherbeenee, Z. (1995). Alihsa wa Tasmeem Al-Tajarub fee Al-Buhooth Al-Nafseah wa Al-Tarbawaeh wa Al-ijtemaeah (Statistic and Analyzing Experiments in Psychological, Educational and Social Research Papers). Cairo: Egyptian Anglo Library.

[2] Askildson, L. (2008). Phonological Bootstrapping in Word Recognition\& Whole Language Reading: A Composite Pedagogy for L2 Reading Development via Concurrent Reading-Listening Protocols and Extensive Reading Approach. Unpublished Doctoral, the University of Arizona, USA.

[3] Brown, H. (1994). Principles of Language Learning and Teaching. New Jersey: Prentice-Hall Regents.

[4] Brown, H. and Mothie, V. (1984). Inside Whole Language. New Hampshire: Heindeman Publishers.

[5] Crawford, J. (1993). The Effects of Whole Language Instruction on Community College Students. Florida: University of Florida.

[6] Dawid, D. (2004). A Whole Language Approach for Foreign Language Writing Using Computers. Unpublished Dissertation. Stony Brook University, New York.

[7] Finocchiaro, M. and Bonomo, M. (1973). The Foreign Language Learner. New York: Regents Publishing Comp Inc.

[8] Freeman, Y., and Freeman, D. (1992). Whole Language for Second Language Learners. Portsmouth, NH: Heinemann.

[9] Gardner, H. (1983). Frames of Mind. New York: Basic Books.

[10] Goodman, K., Goodman, Y. \& Hood, W. (1986). The Whole Language Evaluation Book. Portsmouth, NH: Heinemann Educational Textbooks.

[11] Graham, S. and Haris, K. (1994). The Effects of Whole Language on Children's Writing: A Review of Literature. Educational Psychologist, 29 (4), 187-192.

[12] Harp, B and Brewer, J. (1991). Reading and Writing: Teaching for Connections. New York: Hartcourt Brace College Publishers.

[13] Hersan, M. (1998). The Integration of Reading and Writing through Pair and Group Work. Unpublished Master Thesis. Hacettepe University, Ankara.

[14] Hobson, E. and Schuman, R. (1990). Reading and Writing in High School: A Whole Language Approach. Washington, DC: National Education Association.

[15] Jacobs. H. (1991). Planning for Curriculum Integration, Educational Leadership, 34 (4), p 25-30.

[16] Lake, K. (2001). Integrated curriculum. school improvement research series. Retrieved 4 April, 2008 from www.nwrel. $\mathrm{org} / \mathrm{scpd} / \mathrm{sirs} / 8 / \mathrm{c} 0$ 16.html.

[17] Larsen-Freeman, D. (2000). Techniques and principles in language Teaching. Oxford: OUP.

[18] Lim, H. and Watson, D. (1993). Whole Language Content Classes for Second- language learners, The Reading Teacher, 46 (5), 384-394. Retrieved Feb, 1993 from: http://web.ebscohost.com.ezproxy. yu.edu.jo/ehost/detail?vid=5\&hid=9\&sId=031614ebc7f7-481e-b1e9-c9942163e088\%40sessio gr4\&bdata= JnNpdGU9ZW hvc 3QtbGl2ZQ\%3d\%3d\#db=lfh\& AN=9303240538.

[19] Lipson, Y. (1993). Integration and the Matic Teaching Integration to Improve Teaching and Learning. Language Arts, 70 (4), 252- 263.

[20] Long, N. (1996). An Integrated Approach to Reading, Writing and History with Developmental Minority College Students. Unpublished Dissertation, University of Central Florida, Florida.

[21] Newman, J. (1985). Whole Language: Theory in use. Portsmouth, NH: Heinemann Educational Books.

[22] Omaggio, A. (2001). Teaching language in Context. Boston: Heinle and Heinle.

[23] Rigg, P. (1991). Whole Language in TESOL. TESOL Quarterly 25 (3), 521-542.

[24] Shatnawi, M. (2005). Designing an EFL Integrative Teaching Program Based on the Whole Language Approach and measuring its effect on the Basic Stage Students' Achievement in English. Unpublished Doctoral Dissertation, Amman Arab University for Graduate Studies, Amman.

[25] Smith, F. (1983). Essays into Literacy. Portsmouth, NH: Heinnman Educational Books.

[26] Weaver, C. (1990). Understanding Whole Language. Toronto: Irwin Publishers

[27] Wixon, K., Peter, C. \& Potter, S. (1996). The case for integrated standards in English language arts. Language Arts, 73 (1), $20-$ 29. 
Oraib Hmoud Al-Faoury is an assistant professor of translation courses, TEFL and CALL in the English Language Department at Al-Imam Mohammad Ibn Saud Islamic University\ Riyadh. She has been teaching English at different colleges and universities for more than ten years. She has written and published research in creative short stories, giftedness, child rights and Whole Language Approach.

Nasser M. Freahat is an assistant professor of English Language Curricula and Instruction. He is teaching English language courses for graduate and undergraduate students in the English Language Department at Imam Mohammad Ibn Saud Islamic University-Riyadh, Saudi Arabia. His research interests include Language Acquisition, Teaching Reading Comprehension, Discourse Analysis. 